\title{
Life history and phenology of Phylloicus pulchrus (Trichoptera: Calamoceratidae) in a tropical rainforest stream of Puerto Rico
}

\author{
Limarie J. Reyes-Torres ${ }^{1,2}$ \& Alonso Ramírez ${ }^{2}$ \\ 1. Department of Biological Sciences, University of Southern Mississippi, Hattiesburg, MS, 39460; \\ limarie.reyestorres@usm.edu \\ 2. Department of Environmental Sciences, University of Puerto Rico, San Juan, Puerto Rico 00931; \\ aramirez@ramirezlab.net
}

Received 30-X-2017. Corrected 12-II-2018. Accepted 08-III-2018.

\begin{abstract}
Caddisflies are abundant, diverse, and important insects in freshwater ecosystems. However our knowledge on their life history is incomplete, in particular for the Neotropics. The objectives of this study were to describe the life history and phenology of Phylloicus pulchrus in the Luquillo Experimental Forest, Puerto Rico. Eggs and larvae were reared to determine the species lifespan and time in each instar. Larval instars were determined based on a head width vs. pronotal suture length correlation $(\mathrm{N}=120)$. Larvae and benthic leaf litter were sampled monthly at a headwater stream for a year; all specimens were classified into instars based on their case size. Adult $P$. pulchrus were sampled monthly for a year with a light trap and at various times with a Malaise trap. Monthly environmental variables were related to species and sex abundance. There was a gradient of egg development where eggs (within compound masses) closest to the water were more developed. There were five larval instars and reared larvae showed longer development times and more variable body measurements in later instars. The best correlation for larval instar determination was case length-head width (Pearson= $0.90, \mathrm{P}=$ $2.2 \mathrm{e}^{-16}, \mathrm{~N}=120$ ). Phylloicus pulchrus has a multivoltine life cycle, with asynchronous larval development. Adult abundance was low. First to third instar larvae were influenced significantly by rainfall and rainfall seasonality had a negative significant effect on second instar larval abundance (ANOVA=7.45, P=0.02).Compound egg masses were probably oviposited by different females that gathered for oviposition. Phylloicus pulchrus follows the predominant developmental characteristic of Trichoptera of having five larval stages. Development times were longer than expected (longest times for a Phylloicus species) and may be an effect of laboratory rearing. The influence of rainfall (and seasonality) on different larval instars highlights the importance of this variable on early larval development. The cause of low adult abundance remains unclear, but may be related to low emergence rates and trap efficiency. Rev. Biol. Trop. 66(2): 814-825. Epub 2018 June 01.
\end{abstract}

Key words: caddisfly; tropical streams; environmental variables; rainfall seasonality; instar determination; body-case relation.

Life history information is fundamental for understanding the evolution, taxonomy, and ecology of an organism, its relationships within aquatic communities, and the role of individual species in ecosystems (Norwood \& Stewart, 2002). In addition, knowledge of life histories is important when developing conservation strategies for biological communities and developing estimates of production (Norwood
\& Stewart, 2002). Our knowledge of caddisfly life history is incomplete (Celina \& Rueda, 2010). Despite their abundance, diversity, and importance in freshwater ecosystems, comprehensive life histories are known for less than 10 $\%$ of the Nearctic fauna (Norwood \& Stewart, 2002) and even less for the Neotropical region (Mendez \& Resh, 2007), where the order is more diverse (Morse, 2017). 
Important events in the life history of caddisflies (e.g., eclosion, pupation, emergence, mating, and oviposition) are influenced and triggered by environmental variables. Temperature changes, rainfall patterns, and streamflow variations, for example, play important roles in determining the timing of caddisfly life history events (Lund, Wissinger, \& Peckarsky, 2016). Studying phenological aspects of caddisflies allows us to understand the interactions between these organisms and their environment, which provides a window to comprehend their role in stream ecosystems.

Available life history information on Phylloicus (Müller, 1880) focuses mainly in larval feeding habits and case building behavior (Norwood \& Stewart, 2002; Rincón \& Martínez, 2006). Little is known about the life history and phenology of these species, information that is needed to better understand their role and influence on leaf processing and energy fluxes in tropical streams. Phylloicus is particularly abundant in pools at the stream edge and in small forested streams (Springer, 2010). In Puerto Rico, Phylloicus pulchrus (Flint,1964), a species whose larvae builds its case from overlapping circles of excised stream leaf detritus, is the only species of Calamoceratidae (Ulmer, 1905) (Flint, 1964; Morse, 2017) and is abundant (up to 80 larvae per liter of wet leaf litter in Buruquena stream, Luquillo Experimental Forest). There are only three studies focused on P. pulchrus in Puerto Rico. First, the species was described by Flint (1964) and then studied in a Trichoptera emergence and phenology study (Flint \& Masteller, 1993) at El Verde Field Station, in which emergence patterns were related to precipitation. Recently, a study at El Verde Field Station (Cardona-Rivera \& Ramírez, 2016), revealed P. pulchrus larvae predating on Telebasis vulnerata (Odonata: Coenagrionidae) eggs.

The objectives of this study were to describe the life history and phenology of $P$. pulchrus in the Luquillo Experimental Forest, Puerto Rico and to determine the environmental factors that influence the life history and phenology of the species. In terms of life history, we expected P. pulchrus to follow patterns similar to those found for the genus in other geographic areas: female lay egg masses over shallow pools (along banks and attached to rocks) and egg development takes between 10 to 15 days (Jackson \& Sweeney, 1995). Another expectation was that larvae would inhabit slow flow areas in streams where leaf litter accumulates (Springer, 2010), would have five developmental stages lasting in total from 75 to 115 days (Jackson \& Sweeney, 1995). Pupal development would last approximately 15 days (Springer, 2010) and total larval development (sum of larval and pupal time) would be around 90 to 130 days (Jackson \& Sweeney, 1995). In addition, adult sex ratios would be skewed towards females (Flint \& Masteller, 1993; Almeida \& Marinoni, 2000; Marinoni \& Almeida, 2000).

Phenologically, P. pulchrus was expected to have a multivoltine life cycle, with asynchronous larval development and all larval instars present simultaneously throughout the year as exhibited by other tropical aquatic species (Jackson \& Sweeney, 1995; Jacobsen, Cressa, Mathooko, \& Dudgeon, 2008; Springer, 2010). Also environmental variables, such as temperature, precipitation, streamflow, and leaf litter availability would influence $P$. pulchrus life history and phenology, affecting both the adult and larval stages (McElravy, Wolda, \& Resh, 1982; Springer, 2010). Increases in rainfall and streamflow create disturbances that may displace caddisfly larvae (Bispo, Oliveira, CrisciBispo \& Sousa, 2004) and their food sources, while higher leaf litter inputs favor development of shredding larvae (Bispo et al., 2004). Higher temperature and rainfall increase caddisfly emergence and adult abundance (McElravy et al., 1982).

\section{MATERIALS AND METHODS}

Study Site: El Verde Field Station is within the Luquillo Experimental Forest (LEF) $\left(18^{\circ} 19^{\prime} 24.11^{\prime \prime} \mathrm{N}-65^{\circ} 49^{\prime} 23.15^{\prime \prime} \mathrm{W}\right)$, in the northeastern region of Puerto Rico. There is slight rainfall seasonality, however a dry period 
can be observed during the first part of the year (McDowell et al., 2012). El Verde receives 200 to $300 \mathrm{~mm}$ of mean monthly precipitation, mean daily air temperature varies from 21.5 to $23.5{ }^{\circ} \mathrm{C}$ (McDowell et al., 2012) and water temperatures vary from 20.0 to 26.0 ${ }^{\circ} \mathrm{C}$ (Rincón \& Covich, 2014). Steep streams with pools and riffles are typical of the area (McDowell et al., 2012) and riparian vegetation is dominated by Dacryodes excelsa (tabonuco), Cecropia scheberiana (yagrumo) and Prestoea acuminate (sierra palm) (McDowell et al., 2012). Buruquena stream (18 19'24.11" $\left.\mathrm{N}-65^{\circ} 49^{\prime} 23.15^{\prime \prime} \mathrm{W}\right)$ is a first order stream located next to the station in tabonuco forest (lower montane rainforest). A transect of $100 \mathrm{~m}$ (divided into sub-transects of $5 \mathrm{~m}$ ) was established at the stream, elevation changes from 366 to $335 \mathrm{~m}$ along the transect. The first (0-15 $\mathrm{m})$ and last (85-100 m) sub-transects have steep slopes with large boulders. A mixed canopy cover produces different leaf litter inputs and light availability along the study transect, with denser canopy cover from $55 \mathrm{~m}$ forth.

Life history: To determine lifespan and time in each instar, P. pulchrus eggs and larvae collected from the stream were reared in chambers that simulated the species natural conditions, at the Aquatic Ecology Laboratory at the University of Puerto Rico, Rio Piedras. A rectangular plastic aquaria $(38 \times 53 \times 14 \mathrm{~cm})$ was filled to one third its capacity with aerated stream water (temperature $=23{ }^{\circ} \mathrm{C}$, regulated with an Aqueon 250W Pro Heater) and we used circular plastic chambers $(10.16 \mathrm{~cm}$ diameter, $5.08 \mathrm{~cm}$ depth) with screen windows $(3.8 \mathrm{x}$ $5.1 \mathrm{~cm}, 90 \mu \mathrm{m}$ mesh) to place larvae inside the aquaria. Chambers contained rinsed senescent leaves collected from the stream, which serve for larval consumption and case building.

Egg masses collected at the stream were observed for later description, collected, separated with soft forceps in approximately equal portions and placed in the chambers. Phylloicus pulchrus development was observed periodically under the microscope until emergence. Every two weeks, water was changed (to prevent leaf leaching buildup in the aquaria based on previous observations) and new senescent leaves collected from the same stream were added to the chambers. As larvae reached their fourth and fifth instars, chambers were removed and stream substrate (sand and gravel for pupal case construction) and cobbles (for pupal attachment) were placed on the aquarium bottom. A screen was placed over the aquarium to prevent emerged adults from escaping. Pupal exuvia were collected to determine pupation time.

To verify the presence of the five larval instars (common in Calamoceratidae, Wiggins, 2004), larval head width (mm) was plotted against pronotal suture length $(\mathrm{mm})$ (Norwood $\&$ Stewart, 2002). These body dimensions are more precise predictors than body length to identify instars, due to the high sclerotization of the head and pronotum, while body length may change as a result of body expansion caused by the ethanol. Measurements were obtained by placing the specimens under a dissecting microscope with $1 \mathrm{~mm}$ paper grid, taking pictures and using the Image $\mathrm{J}$ software (Rasband, 2016).

Phenology: Larvae and benthic stream leaf litter were sampled monthly from February 2016 to February 2017. Percent of leaf litter covering the stream channel was estimated for each $5 \mathrm{~m}$ sub-transect by two observers and the average was recorded for each stream sub-transect along the $100 \mathrm{~m}$ transect. Leaf litter was collected manually from six randomly selected sub-transects. Leaf litter was placed on plastic trays in the field; larvae were removed by eye using soft forceps and preserved in 70 $\%$ ethanol. Compressed leaf litter volume was measured using a $1 \mathrm{~L}$ plastic container and larval abundance was calculated as number of larvae per $\mathrm{ml}$ of wet leaf litter.

Larval body measurements (head width $[\mathrm{mm}]$ and pronotal suture length $[\mathrm{mm}])$ and case measurements (length $[\mathrm{mm}]$ and width [mm] at largest case width point) were obtained by taking pictures of the specimens under a dissecting microscope, using a $1 \mathrm{~mm}$ paper grid 
and Image J software (Rasband, 2016). Body measurements were correlated with case measurements and the best correlation was used to determine larval instars based on case size (in the laboratory) of the collected and preserved larvae throughout the year (February 2016 February 2017).

Phylloicus pulchrus adults were sampled monthly for one year (July 2015 to July 2016) using an UV/fluorescent light trap and aspirators. The light trap (white sheet hung over a rope, illuminated with florescent and UV lights powered by a $12 \mathrm{v}$ car battery) was placed next to the study stream (approximately $4.5 \mathrm{~m}$ ) for two hours after sunset (usually 19:00-21:00). In addition, several diurnal malaise trap collections were made between February 2017 and April 2017, to compare adult diurnal and nocturnal abundance. A malaise trap was set for six hours (6:00-12:00 or 12:00-18:00) approximately $20 \mathrm{~m}$ from the stream. Specimens were mounted on pins or preserved in ethanol $70 \%$. Sex was determined based on external genitalia morphology (Flint, 1964) of the ninth and tenth segments of the abdomen. Monthly adult abundance was analyzed as total and by sex.

Relation with Environmental Variables: Temperature (LUQ-LTER, 2017a-b) and rainfall (LUQ-LTER, 2017c) data were obtained from the Luquillo Long Term Ecological Research database. Moonlight data for each sampling night with the light trap, was retrieved from The United States Naval Observatory webpage (USNO, 2016) and was used to control for moonlight interference with the light trap as lunar cycle may influence the number or individuals collected (McElravy et al., 1982). Discharge was measured using an Onset Computers automatic sensor (pressure transducer, programmed to read every 15 minutes).

All statistical analyses were performed using R Studio (RStudio Team, 2016). A two sample t-test was used to determine significant differences between the monthly abundance of adult $P$. pulchrus of each sex. Stepwise multiple linear regressions were used to relate the predictor environmental variables (temperature $\left[{ }^{\circ} \mathrm{C}\right]$, rainfall $[\mathrm{mm}]$, discharge $\left[\mathrm{m}^{3} / \mathrm{s}\right]$, moonlight [\%], and leaf litter availability $[\mathrm{ml}]$ ) with the response variables (larval and adult abundance). Rainfall ( $\mathrm{mm}$ ) from previous months (up to six months before sampling) was analyzed individually (month by month) to account for the influence of rainfall patterns, and accumulated (sum of monthly rainfalls) to account for rainfall accumulation. Relationships with environmental variables were assessed for total $P$. pulchrus adult abundance and by sex. A multiple regression analysis was performed consecutively with the removal of the weakest predictor variable based on Akaike Information Criteria (AIC), which enabled the determination of the best model (i.e. the one where predictor variables best explain the data distribution in the response variable, RStudio Team, 2016). Four data assumptions were made and tested prior to running the regression analysis: (1) linear relationship between each predictor and response variable (bivariate scatterplot), (2) homoscedasticity of the errors (scatterplot of the models and each predictor separately), (3) independent (Pearson correlation) and (4) normally distributed variables (transformed using $\log _{10}(\mathrm{x}+1)$ ). Environmental variable regression results were considered significant for Pearson $\geq 0.7$ (Esselman \& Allan, 2010; Sánchez-Ruiz, Ramírez, \& Kelly, 2017) and p-value $<0.05$. After checking for assumptions, ten variables (out of 17) were used to create the larval and adult phenology models (Table 1). As the LEF experiences minor rainfall seasonality (McDowell et al., 2012), P. pulchrus abundance and environmental data was also analyzed by wet and dry period (besides monthly analysis). A Chisquare test was performed to evaluate differences in adult sex abundance (from light traps) per rainfall season. An Analysis of Variance (ANOVA) was performed to assess differences in adult abundance per rainfall season. Another ANOVA was performed to evaluate differences in larval abundance per rainfall season. 
TABLE 1

Variables (and their abbreviations) used to create larval and adult models

\begin{tabular}{|c|c|c|}
\hline Environmental variable & Abbreviation & Specification \\
\hline Rainfall & Rain & Only for larval models \\
\hline Rainfall from one month ago (mm) & Rain-1 & \\
\hline Rainfall from two months ago(mm) & Rain-2 & \\
\hline Rainfall from three months ago (mm) & Rain-3 & \\
\hline Rainfall from four months ago (mm) & Rain-4 & \\
\hline Rainfall from five months ago (mm) & Rain-5 & \\
\hline Rainfall from six months ago (mm) & Rain-6 & \\
\hline Mean monthly temperature $\left({ }^{\circ} \mathrm{C}\right)$ & Temp & \\
\hline Leaf litter ${ }_{B}(\mathrm{ml})^{*}$ & Leaf $_{B}$ & \\
\hline Leaf $\operatorname{litter}_{\mathrm{P}}\left(\mathrm{gm}^{2}\right)^{*}$ & Leaf $_{\mathrm{P}}$ & \\
\hline Average monthly discharge $\left(\mathrm{m}^{3} / \mathrm{sec}\right)$ & Disch & Only for adult models \\
\hline
\end{tabular}

Leaf litter ${ }_{B}$ represents benthic leaf litter from the study stream while leaf litter ${ }_{p}$ represents leaves, flowers, fruit, wood and miscellaneous material (e.g. bark) collected from baskets in another stream (Prieta) at the station (data used for comparison).

\section{RESULTS}

Life History: Eggs were collected on different sampling dates (December 27, 2016 and January 21, 2017). The first collection comprised of a medium size egg mass (approximately 800 eggs) that was found submerged in a shallow pool of the stream. The second collection was a combination of one large egg mass (more than 4000 eggs) and several adjacent smaller ones (approximately 200 eggs each), all found attached to a leaf and twigs that were partly submerged on a stream pool. The medium and large egg masses were formed by many small masses. A gradient of egg development was observed in the large egg mass, where the upper portion (farthest from water surface) contained less developed eggs (solid white chorion), while the lower portion (closest to water surface) contained more developed eggs (full embryo) and larvae. In addition, small and medium egg masses were collected from the sides of boulders in the stream channel.

First instar larvae from reared eggs constructed provisional tubular cases with detritus before adding leaf fragments. Larvae were found on slow flow areas of the stream where leaf litter accumulated. There were five larval instars (Fig. 1), based on larval body measurements (Table 2). Differences between the first and second instars body measurements were not as definitive as in the other larval instars (Fig. 1). Measurements from the fifth (last) larval instar were more dispersed (Fig. 1). Reared larvae showed longer development times (1.5x-2.5x longer) in later instars (Table $2)$. No behavioral observations of molting were made as larval instar change was determined by case measurements. Pupae were found attached, with the anterior end of the case strongly fastened to the underside of boulders and cobbles and the posterior end filled with gravel. Pupal cases were constructed with bark and thick leaves which were fragmented by conspecifics. Pupal exuvias were found and used as signal of adult emergence.

Phenology: Larval instars were assigned based on the case length versus head width correlation (Pearson=0.90, $\mathrm{P}=2.2 \mathrm{e}^{-16}, \mathrm{~N}=120$ ) (Table 2). Phylloicus pulchrus has a multivoltine life cycle with continuous cohorts observed throughout the year (Fig. 2). A total of 1347 larvae were collected and categorized by instar. Larval development is asynchronous. Second to fifth larval instars are present simultaneously throughout the year (Fig. 2), with exception of the first instar which was not collected on two months (July and August). February 2016, 


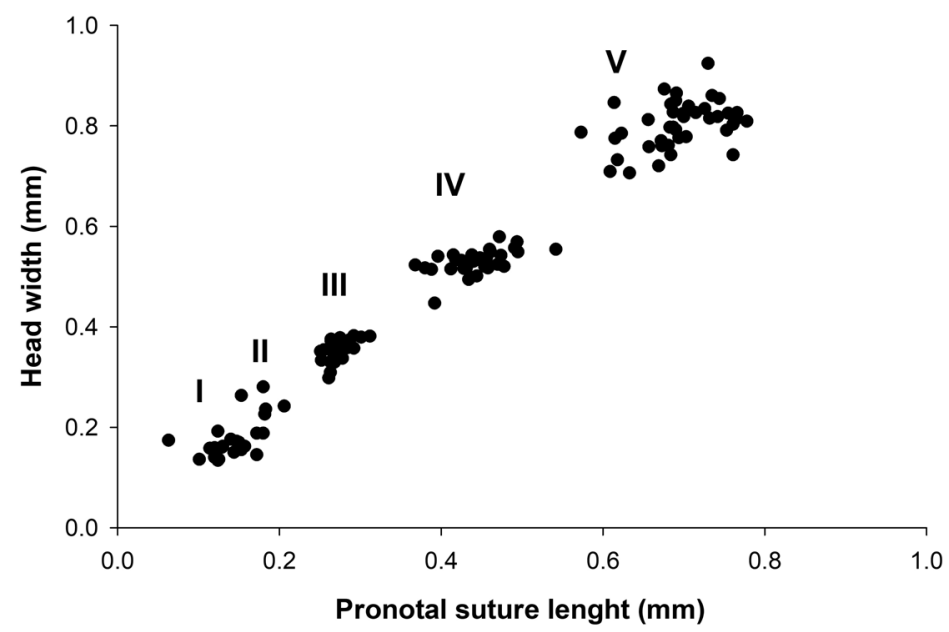

Fig. 1. Relation between the pronotal suture length and head width in P. pulchrus $(\mathrm{N}=120)$. Groups correspond to the proposed five larval instars.

TABLE 2

P. pulchrus development times and larval body-case measurements used to classify instars

\begin{tabular}{ccccc} 
Instar & Head width $(\mathrm{mm})$ & Suture length $(\mathrm{mm})$ & Case length $(\mathrm{mm})$ & Average time (days) within instar \\
Egg & - & - & - & 10 \\
Instar 1 & $0.12-0.20$ & $0.07-0.16$ & $<0.92$ & 13 \\
Instar 2 & $0.18-0.28$ & $0.16-0.21$ & $0.93-3.3$ & 15 \\
Instar 3 & $0.29-0.39$ & $0.25-0.32$ & $3.73-6.49$ & 19 \\
Instar 4 & $0.44-0.58$ & $0.37-0.54$ & $06.53-12.23$ & 21 \\
Instar 5 & $0.70-0.92$ & $0.58-0.78$ & $>12.93$ & 32 \\
Pupae & - & - & - & 22 \\
Total development & - & - & - & 132 \\
\hline
\end{tabular}

Eggs and pupae dimensions were not measured. Days for the egg stage were estimated based on evaluation of newer eggs (full white chorion) in reared egg masses, as oviposition was not observed in the field.



Fig. 2. Relative abundance of P. pulchrus larvae by instar and month $(\mathrm{N}=1347)$ at the Luquillo Experimental Forest. 
TABLE 3

Best Akaike Information Criterion (AIC) phenology model for each larval instar

\begin{tabular}{clccc} 
Response variable & \multicolumn{1}{c}{ Model parameters (signal) } & AICc & R adj & P-val \\
Instar 1 & Rain1-Rain6+ & 37.9 & 0.47 & 0.02 \\
Instar 2 & Rain1-Temp-Rain-Rain6+ & 40.1 & 0.82 & 0.002 \\
Instar 3 & Rain2-Leaf - Rain6-Rain-Rain3-Rain1-Rain4-Rain5- & 219.16 & 0.90 & 0.03 \\
Instar 4 & Temp- & 30.33 & 0.23 & 0.07 \\
\hline
\end{tabular}

Model parameter (signal) column indicate the parameters used in each model and the direction, positive (+) or negative (-) of their effect. Model for fifth larval instars excluded all environmental variables and was not included.

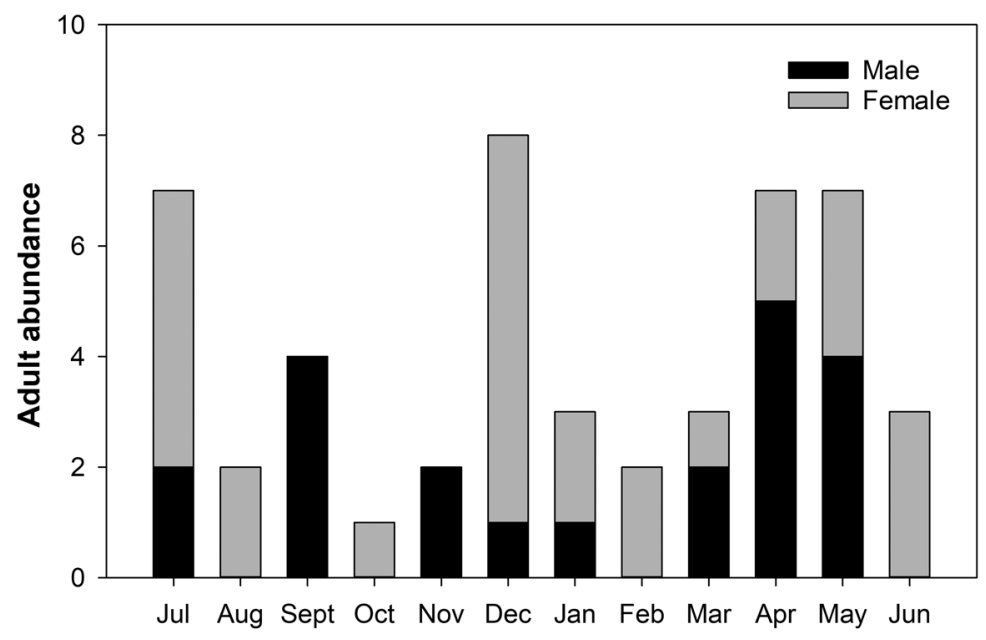

Fig. 3. Monthly P. pulchrus adult abundance and sex from July 2016 to June 2017. Adults were sampled with an UV/fluorescent light.

September 2016, and November 2016 were the months in which first instar larvae were more abundant. Fourth and third instar larvae were the most abundant respectively, monthly and overall (Fig. 2). First instar larvae were the least abundant (Fig. 2). Leaf litter was available in Buruquena stream throughout the year and it varied slightly from month to month. Adult P. pulchrus abundance was low using the light traps (Fig. 3) and nonexistent using the malaise traps during the day. Sex of collected adults throughout the year (Fig. 3) was not significantly different $(\mathrm{T}$ test $=0.85, \mathrm{P}=0.40)$.

Relation with Environmental Variables: In general, a pattern was observed where rainfall and larval abundance of the first three instars were negatively related (Table 3 ). Lower larval abundance for the first three instars was related to increases in rainfall, and rainfall from the previous month or two previous months had the strongest influence on larval abundance (Table $3)$. This was clearly observed for the lowest larval abundance reported (August) which was preceded by a rainfall peak in July. Specifically, first instar larvae had a moderate mixed (negative and positive) influence of rainfall from the same month of sampling and for up to six months before sampling (Table 3). Second instar larvae were strongly (mixed) influenced by the rainfall of the previous month, temperature, rainfall from the same month of sampling, and rainfall from up to six months ago (Table $3)$. Temperature had a negative effect on second instar larvae (Table 3) in which lower larval abundance was observed during higher 
temperatures. Third instar larvae had a strong negative influence of eight of the ten variables used in the larval models (Table 3). Late larval instars were not influenced by rainfall (Table 3). A significant difference in larval abundance by rainfall season was found for second instar larvae only (ANOVA $=7.45, \mathrm{P}=0.02$ ), where higher larval abundance was observed during the dry season. There was no significant effect of environmental variables on adult abundance in general and by sex. Also no significant differences were found between seasons in total adult abundance (ANOVA $=0.003, \mathrm{P}=0.96$ ) or by sex $($ Chi square $=0.97, \mathrm{P}=0.32)$.

\section{DISCUSSION}

The oviposition sites of $P$. pulchrus coincide with previous studies that reported egg masses in shallow pools and attached to surrounding rocks (Jackson \& Sweeney, 1995). Low flow areas of streams provide stable substrate (Bispo et al., 2004) and leaf material for larval consumption and case building, thus is an ideal location for adult females to oviposit and larvae to inhabit. Egg masses found in leaf and twigs are a new report for the species, but are common in other Trichoptera (Springer, 2010). The medium and large egg masses formed by many small masses were probably oviposited by different females that gathered together, as was suggested by the divisions in the egg masses, the high amount of eggs oviposited, and visible differences in development of larvae across the largest egg mass. Other Trichoptera form large aggregations on favored oviposition sites, such as Ulmerochorema (Hydrobiosidae) that has swarming behavior associated with oviposition sites (Lancaster, Downes, \& Reich, 2003; Reich \& Downes, 2003). In the case of P. pulchrus, site selection for oviposition suggest that egg masses might be submerged during high streamflow or as a result of wind moving twigs - which could induce chemical cues that triggers eclosion (Lund et al., 2016).

Phylloicus pulchrus follows the predominant developmental characteristic of
Trichoptera of having five larval stages (Wiggins, 2004). Construction of a provisional debris case was similar to the recorded for first instar larvae of P. ornatus (Norwood \& Stewart, 2002). Monthly and overall higher abundance of fourth and third larval instars respectively may be a result of the broader body and case measurement intervals of these two instars if compared to the others. Similar results were reported for $P$. ornatus, where later instars were more abundant (Norwood \& Stewart, 2002). Larval development times varied slightly from expected as observed in species of Phylloicus (Jackson \& Sweeney, 1995; Norwood \& Stewart, 2002). Phylloicus pulchrus development time (132d) was 60, 22-17 and 18 days greater than the multivoltine asynchronous species $P$. elegans (72d), P. ornatus (110)-115 as reported by Norwood \& Stewart, (2002)- and P. nr ornatus (114), respectively (Jackson \& Sweeney, 1995). Longer development times in $P$. pulchrus may be an effect of laboratory rearing but as of now are the longer development times reported for a Phylloicus species. Overall longer development times of $P$. pulchrus later instars (along with clearer differences between instars), and more dispersed body measurements, coincides with that reported for P. ornatus (Norwood \& Stewart, 2002).

Pupal development times were higher in P. pulchrus compared to other species (Jackson \& Sweeney, 1995; Norwood \& Stewart, 2002), however, we cannot discard this being a result of laboratory conditions (even though simulation of natural conditions was pursued). Similar to other Phylloicus species (Norwood \& Stewart, 2002), P. pulchrus pupal attachment to the underside of cobbles minimizes the chances of getting swept downstream. Phylloicus pulchrus pupal case of bark and tough leaves (fragmented by conspecifics) serve as a stronger pupal defense as tough materials incorporated in pupal cases protect against conspecific feeding during the immobile stage (Norwood \& Stewart, 2002). Gravel attachment to the posterior end of the case, functions as a ballast in the absence of attachment to substrate 
(Norwood \& Stewart, 2002). Even though all the observed pupal cases had substrate in the posterior portion, all were strongly attached to the rocks. In this instance, having the anterior portion of the case strongly attached to the rocks and the posterior end with gravel, may serve as an additional mean of stability, which would be efficient with the high variability in stream discharge at El Verde.

A multivoltine cycle and developmental asynchrony (observed with the continuous cohorts) are expected on a tropical setting due to warmer water temperature, constant resource availability, and low seasonality (Jacobsen et al., 2008; Springer, 2010). Overlapping cohorts of $P$. pulchrus was evidenced by the presence of larvae of all instars and adults almost throughout the year, suggesting that growth, emergence, and reproduction occur continuously. Thus, we conclude that $P$. pulchrus has a multivoltine asynchronous life cycle. This is evidenced by the estimated total development time (132d) which would produce approximately 2.8 cohorts in a year. However, we found overlapping cohorts and more than 3 generations per year should be expected. Multivoltinism and asynchronous development has also been reported for $P$. ornatus and $P$. elegans (Jackson \& Sweeney, 1995; Norwood $\&$ Stewart, 2002). Having a multivoltine cycle has implications on the structure and function of tropical stream ecosystems, for example production of more individuals results in greater secondary production, more rapid recovery from disturbances and the ability to exploit more effectively temporally variable resources (Jackson \& Sweeney, 1995).

The reason for the overall low abundance of adult $P$. pulchrus collected at night (more so if compared with larval abundance) remains unclear, but may be related to low emergence rates or efficiency of the light trap for attracting adults. Low emergence was previously reported in our study area, where an emergence study in Prieta stream, collected only nine adults over a year (Flint \& Masteller, 1993). Similarly, daily light trap collections during two years and a half in Panama only collected 20 Phylloicus adults, one from an unidentified species, and 19 from P. aeneus (McElravy, et al., 1982). Other cause may be that the light trap is not efficiently attracting the adults, especially if they fly high in the canopy as interference from the dense vegetation blocks the trap lights. Adults of various Phylloicus species have been reported as diurnal (Prather, 2003). Phylloicus pulchrus appears to differ from this pattern as we were unable to find it during the day, but were trapped at night.

The studied first order headwater stream can be prone to drastic flow variations due to the flashiness of LEF streams (Schellekens et al., 2004). In addition to flashiness, certain portions of the stream get dry during parts of the year (personal observations), thus together causing habitat changes, loss of connectivity, and a decrease in accessibility. These effects can be tolerated by $P$. pulchrus larvae, as they can attach to rocks and logs during high flows. Possibly P. pulchrus larvae may tolerate extreme flow reductions, as some caddisfly cases are drought resistant as the organic material of the case retains water (Zamora-Muñoz \& Svensson, 1996; Wiggins, 2004), also influencing the higher larval abundance in the stream.

It is known that insect life history is controlled by environmental variables as they influence certain events, like emergence, development and reproduction (McElravy, et al., 1982; Shama, 2007). Different from temperate regions, the tropics are characterized by warm temperatures and low seasonality in biotic and abiotic factors (Flint \& Masteller, 1993; Jackson \& Sweeney, 1995; Jacobsen et al., 2008). Tropical studies show influence of environmental variables on insect life history, that span from weak to strong (Flint \& Masteller, 1993; Jackson \& Sweeney, 1995; Jacobsen et al., 2008). Our results show a strong influence of an environmental variable on $P$. pulchrus larvae and a weak influence on the adults. The low seasonality in the studied variables contributes to somewhat stable conditions, availability of resources all year round (Bispo et al., 2004; Jackson \& Sweeney, 1995; Jacobsen et al., 2008) and no large changes in P. pulchrus 
populations. The influence of rainfall on different larval instars (lower abundance related to increases in rainfall) evidences the importance of this variable on early larval development. Despite low seasonality in environmental variables, rainfall seasonality is important in tropical regions (Bispo et al., 2004) as is the case at the LEF (McDowell et al., 2012) and as it was evidenced with larval phenology and seasonality (lower larval abundance during the rainy season). During the rainy season, a rapid increase in water flow and velocity occurs in small forested streams, leading to disturbances and displacement of the aquatic organisms (Bispo et al., 2004). However rainfall seasonality had little effect on P. pulchrus adults, similar to the results of Flint and Masteller (1993). Lower larval abundance related to higher temperatures may be a masked effect of the strong influence of rainfall on larval abundance and not the actual effect of temperature.

Our study shows the detailed life history and phenology of a tropical caddisfly. These aspects are described here for the first time, and thus contribute to the scarce knowledge related to the life history of tropical caddisflies and caddisflies in general, also improving our understanding of stream ecosystem conditions on insect life cycles.

\section{ACKNOWLEDGMENTS}

We thank Patina Méndez for her detailed feedback, encouragement and refreshing ideas regarding this research and manuscript.

\section{RESUMEN}

Historia de vida y fenología de Phylloicus pulchrus (Trichoptera: Calamoceratidae) en una quebrada de bosque tropical lluvioso de Puerto Rico. Los tricópteros son insectos abundantes, diversos e importantes en los ecosistemas de agua dulce. Sin embargo el conocimiento sobre su historia de vida es incompleto, en particular para el Neotrópico. Los objetivos de este estudio fueron describir la historia de vida y fenología de Phylloicus pulchrus en el Bosque Experimental de Luquillo, Puerto Rico. Huevos y larvas fueron criadas para determinar la extención y tiempo de vida de cada estadio de la especie. Los estadios larvales fueron determinados basados en la correlación del ancho de cabeza vs. largo de la sutura pronotal $(\mathrm{N}=120)$. Se muestrearon larvas y hojarasca béntica mensualmente por un año, todos los especímenes se clasificaron en estadios por el tamaño del estuche. Los adultos de $P$. pulchrus fueron recolectados mensualmente por un año utilizando una trampa de luz y varias recolectas con una trampa Malaise. Datos mensuales de variables ambientales fueron usados para explicar la abundancia total y por sexo de la especie. Se detectó un gradiente de desarrollo de los huevos donde los huevos (dentro de masa compuesta) más cercanos al agua estaban más desarrollados. Fueron cinco los estadios larvales y las larvas criadas mostraron tiempos de desarrollo más largos y mayor dispersión en las medidas corporales de los estadios tardíos. La mejor correlación para la determinación de estadios fue largo del estuche-ancho de cabeza (Pearson=0.90, $\mathrm{P}=2.2 \mathrm{e}^{-16}, \mathrm{~N}=120$ ). Phylloicus pulchrus tiene un ciclo de vida multivoltino con desarrollo larval asíncrono. La abundancia de adultos fue baja. Los primeros tres estadios larvales fueron influenciados significativamente por la lluvia y la estacionalidad de la lluvia tuvo un efecto significativo en la abundancia del segundo estadio larval (ANOVA=7.45, $\mathrm{P}=0.02$ ). Las masas de huevo complejas fueron probablemente ovipositadas por diferentes hembras que se reunieron para oviponer. Phylloicus pulchrus mantiene la característica de desarrollo predominante en Trichoptera de tener cinco estadios larvales. Los tiempos de desarrollo fueron mayores a lo esperado (los más largos para una especie de Phylloicus) y puede ser un efecto de la crianza en el laboratorio. El ciclo de vida multivoltino asíncrono observado es el esperado en un entorno tropical debido a las temperaturas más cálidas del agua, la disponibilidad constante de recursos y la baja estacionalidad. La causa de la poca abundancia de adultos permanece incierta, aunque puede estar relacionada con bajas tasas de emergencia y la eficiencia de la trampa de luz. La influencia de la lluvia (y su estacionalidad) en diferentes estadios larvales evidencian la importancia de esta variable en el desarrollo larval temprano.

Palabras clave: tricópteros; ríos tropicales; variables ambientales; estacionalidad; determinación de estadios; correlaciones cuerpo-estuche.

\section{REFERENCES}

Almeida, G., \& Marinoni, L. (2000). Abundância e sazonal idade das espécies de Leptoceridae (Insecta, Trichoptera) capturadas com armadilha luminosa no Estado do Paraná, Brasil. Revista Brasileira de Zoologia, 17(2), 347-359. doi: 10.1590/S0101-81752000000200005

Bispo, P., Oliveira, L., Crisci-Bispo, V., \& Sousa, K. (2004). Environmental factors influencing distribution and abundance of trichopteran larvae in Central Brazilian mountain streams. Studies on Neotropical Fauna and Environment, 39(3), 233-237. doi: $10.1080 / 01650520412331271710$ 
Cardona-Rivera, G. A., \& Ramírez, A. (2016) Predation of Telebasis vulnerata (Odonata: Coenagrionidae) eggs by detritivorous caddisfly larva, Phylloicus pulchrus (Trichoptera: Calamoceratidae). International Journal of Odonatology, 19(4), 253-256. doi: $10.1080 / 13887890.2016 .1258372$

Celina, M., \& Rueda, P. (2010). Trophic analysis of two species of Atopsyche (Trichoptera: Hydrobiosidae). Limnologica, 40, 61-66. doi: 10.1016/j. limno.2008.07.004

Esselman, P. C., \& Allan, J. D. (2010). Relative influences of catchment-and reach-scale abiotic factors on freshwater fish communities in rivers of northeastern Mesoamerica. Ecology of Freshwater Fish, 19(3), 439-454. doi: 10.1111/j.1600-0633.2010.00430.x

Flint, O. S. (1964). The Caddisflies (Trichoptera) of Puerto Rico (Report No. 40). Puerto Rico: University of Puerto Rico (Río Piedras Campus) Agricultural Experiment Station.

Flint Jr, O. S., \& Masteller, E. C. (1993). Emergence composition and phenology of Trichoptera from a tropical rainforest stream at El Verde, Puerto Rico. Journal of the Kansas Entomological Society, 140-150.

Jackson, J., \& Sweeney, B. (1995). Egg and Larval Development Times for 35 Species of Tropical Stream Insects from Costa Rica. Journal of the North American Benthological Society, 14(1), 115-130. doi: $10.2307 / 1467728$

Jacobsen, D., Cressa, C., Mathooko, J., \& Dudgeon, D. (2008) Chapter 4: Macroinvertebrates: Composition, Life Histories and Production. Tropical Stream Eco$\log y, 65-105$

Lancaster, J., Downes, B. J., \& Reich, P. (2003). Linking landscape patterns of resource distribution with models of aggregation in ovipositing stream insects. Journal of Animal Ecology, 72(6), 969-978. doi: 10.1046/j.1365-2656.2003.00764.x

Lund, J., Wissinger, S., \& Peckarsky, B. (2016). Caddisfly behavioral responses to drying cues in temporary ponds: implications for effects of climate change. Freshwater Science, 35(2), 619-630. doi: $10.1086 / 685583$

Luquillo Long Term Ecological Research data sets. (20102017). evmn2010-current.csv. [Data file]. Retrieved from http://luq.lternet.edu/data/luqmetadata17

Luquillo Long Term Ecological Research data sets. (20102017). evmx2010-current.csv. [Data file]. Retrieved from http://luq.1ternet.edu/data/luqmetadata16

Luquillo Long Term Ecological Research data sets. (20102017). evra2010-current.csv. [Data file]. Retrieved from http://luq.lternet.edu/data/luqmetadata14
Marinoni, L., \& Almeida, G. (2000). Abundância e sazonalidade das espécies de Hydropsychidae (Insecta, Trichoptera) capturadas em armadilha luminosa no Estado do Paraná, Brasil. Revista Brasileira de Zoologia, 17(1), 283-299. doi: 10.1590/ S0101-81752000000200005

Mendez, P. K., \& Resh, V. H. (2007). What aspects of the life history of Trichoptera have been studied? In J. Buenos-Soria, R. Barba-Álvarez, \& B. Armitage (Eds.), Proceedings of the XIIth International Symposium on Trichoptera (pp 191-195). Ohio: The Caddis Press.

McDowell, W. H., Scatena, F. N., Waide, R. B., Brokaw, N., Camilo, G. R., Covich, A. P., \& Zimmerman, J. (2012). Geographic and Ecological Setting of the Luquillo Mountains. In N. Brokaw, T. A. Crowl, A. E. Lugo, W. H. McDowell, F. N. Scatena, R. B. Waide, \& M. R. Willig (Eds.), A Caribbean Forest Tapestry, The multidimensional nature of disturbance and response (pp.72-163). New York: Oxford University Press.

McElravy, E. P., Wolda, H., \& Resh, V. H. (1982). Seasonality and annual variability of caddisfly adults (Trichoptera) in a "non-seasonal" tropical environment. Archiv fur Hydrobiologie, 94, 302-317.

Morse, J. C. (2017). Trichoptera World Checklist. Retrieved from http://entweb.clemson.edu/database/trichopt/index.htm

Norwood, J. C., \& Stewart, K. W. (2002). Life history and case-building behavior of Phylloicus ornatus (Trichoptera: Calamoceratidae) in two spring-fed streams in Texas. Annals of the Entomological Society of America, 95(1), 44-56. doi: 10.1603/0013-8746(2002)095[0044:LHACBB]2.0. $\mathrm{CO} ; 2$

Prather, A. L. (2003). Revision of the neotropical caddisfly genus Phylloicus (Trichoptera: Calamoceratidae). Zootaxa, 275(1), 1-214. doi: 10.11646/ zootaxa 435.1 .1

Rasband, W. S. (2016). ImageJ (Version 1.50e) [Java 1.8.0 121]. Available from https://imagej.nih.gov/ij/

Reich, P., \& Downes, B. J. (2003). Experimental evidence for physical cues involved in oviposition site selection of lotic hydrobiosid caddis flies. Oecologia, 136(3), 465-475. doi: 10.1007/s00442-003-1284-6

Rincón, J., \& Covich, A. (2014). Effects of insect and decapod exclusion and leaf litter species identity on breakdown rates in a tropical headwater stream. Revista de Biología Tropical, 62(Suppl. 2), 143-154.

Rincón, J., \& Martínez, I. (2006). Food quality and feeding preferences of Phylloicus sp. (Trichoptera: Calamoceratidae). Journal of the North American Benthological Society, 25(1), 209-215. doi: 10.1899/0887-3593(2006)25[209:FQAFPO]2.0. $\mathrm{CO} ; 2$ 
RStudio Team. (2016). RStudio (Version 3.4.1). Retrieved from http://www.rstudio.com/

Sánchez-Ruiz, J. A., Ramírez, A., \& Kelly, S. P. (2017). Decreases in the size of riparian orb webs along an urbanization gradient. Journal of Arachnology, 45, 248-252. doi: 10.1636/JoA-S-16-076.1

Schellekens, J., Scatena, F. N., Bruijnzeel, L. A., Van Dijk, A. I. J. M., Groen, M. M. A., \& Van Hogezand, R. J. P. (2004). Stormflow generation in a small rainforest catchment in the Luquillo Experimental Forest, Puerto Rico. Hydrological Processes, 18(3), 505-530. doi: 10.1002/hyp. 1335

Shama, L. (2007). Population persistence in temporary streams: plasticity and gene flow in an alpine caddisfly (Doctoral Thesis: ETH No. 16959). Swiss Federal Institute of Technology, Zürich.
Springer, M. (2010). Macroinvertebrados de Agua Dulce de Costa Rica I, Capítulo 7: Trichoptera. Revista de Biología Tropical, 58(4), 151-181.

United States Naval Observatory. (2016). Complete Sun and Moon Data for one Day [Data file]. Retrieved from http://aa.usno.navy.mil/data/docs/RS_OneDay. php

Wiggins, G. B. (2004). Caddisflies, The Underwater Architects. Toronto, Canada: University of Toronto Press Inc.

Zamora-Muñoz, C., \& Svensson, B. (1996). Survival of caddis larvae in relation to their case material in a group of temporary and permanent pools. Freshwater Biology, 36, 23-31. doi: 10.1046/j.1365-2427.1996.00057.x 